University of Nebraska - Lincoln

DigitalCommons@University of Nebraska - Lincoln

Biological Systems Engineering: Papers and

Publications

Biological Systems Engineering

$12-19-2013$

\title{
Temperature-dependent Dielectric and Thermal Properties of Whey Protein Gel and Mashed Potato
}

\author{
Jiajia Chen \\ University of Nebraska-Lincoln, jiajia.chen@unl.edu \\ Krishnamoorthy Pitchai \\ University of Nebraska at Lincoln, s-kpitcha1@unl.edu \\ Sohan Birla \\ ConAgra Foods, Omaha, NE \\ Ricardo Gonzalez \\ ConAgra Foods, Omaha, NE \\ David Jones \\ University of Nebraska-Lincoln, david.jones@unl.edu \\ See next page for additional authors
}

Follow this and additional works at: https://digitalcommons.unl.edu/biosysengfacpub

Part of the Biological Engineering Commons

Chen, Jiajia; Pitchai, Krishnamoorthy; Birla, Sohan; Gonzalez, Ricardo; Jones, David; and Subbiah, Jeyamkondan, "Temperature-dependent Dielectric and Thermal Properties of Whey Protein Gel and Mashed Potato" (2013). Biological Systems Engineering: Papers and Publications. 326.

https://digitalcommons.unl.edu/biosysengfacpub/326

This Article is brought to you for free and open access by the Biological Systems Engineering at DigitalCommons@University of Nebraska - Lincoln. It has been accepted for inclusion in Biological Systems Engineering: Papers and Publications by an authorized administrator of DigitalCommons@University of Nebraska Lincoln. 


\section{Authors}

Jiajia Chen, Krishnamoorthy Pitchai, Sohan Birla, Ricardo Gonzalez, David Jones, and Jeyamkondan Subbiah 


\title{
TEMPERATURE-DEPENDENT DIELECTRIC AND THERMAL PROPERTIES OF WHEY PROTEIN GEL AND MASHED POTATO
}

\author{
J. Chen, K. Pitchai, S. Birla, R. Gonzalez, D. Jones, J. Subbiah
}

\begin{abstract}
Temperature-dependent dielectric properties (dielectric constant and dielectric loss factor) and thermal properties (thermal conductivity and specific heat capacity) of whey protein gel and mashed potato were measured from $-20^{\circ} \mathrm{C}$ to $100^{\circ} \mathrm{C}$. A dielectric properties measurement system and a multipoint temperature calibration protocol were developed. The system consists of an impedance analyzer, a high-temperature coaxial cable, a high-temperature coaxial probe, a micro-climatic chamber, and a metal sample holder. Calibrations at two temperatures $\left(25^{\circ} \mathrm{C}\right.$ and $\left.85^{\circ} \mathrm{C}\right)$ were sufficient to accurately measure the dielectric properties of foods from frozen to hot temperatures. Dielectric constant and dielectric loss factor both rapidly increased from $-20^{\circ} \mathrm{C}$ to $0^{\circ} \mathrm{C}$. Thereafter, dielectric constant linearly decreased from $0^{\circ} \mathrm{C}$ to $100^{\circ} \mathrm{C}$, while dielectric loss factor decreased first and then linearly increased. The thermal conductivity values of whey protein gel and mashed potato decreased with increasing temperature in the frozen range and did not change considerably after thawing. The latent heat of fusion values of whey protein gel and mashed potato were 219.1 and $186.8 \mathrm{~kJ}^{\mathrm{kg}} \mathrm{kg}^{-1}$, respectively. The temperature-dependent material properties can be used in microwave heat transfer models for improving heating performance of foods in domestic microwave ovens.
\end{abstract}

Keywords. Dielectric constant, Dielectric loss factor, Mashed potato, Specific heat capacity, Thermal conductivity, Whey protein gel.

$\mathrm{M}$ icrowave heating of food in domestic microwave ovens is rapid and convenient. However, the major issue in microwave heating of frozen food is nonuniform heating, which is due in part to dramatic variations in properties between ice and water. Ensuring the safety of microwave heating of frozen foods while optimizing the quality of heating are the major drivers for improving microwave heating uniformity. Understanding how microwaves interact with food will help food scientists develop packaged food products that provide better cooking performance in domestic microwave ovens in terms of heating uniformity (Bradshaw et al., 1997; Gunasekaran and Yang, 2007; Rakesh et al., 2009; Ryynänen et al., 2004). A coupled electromagnetic and heat transfer model is a promising tool for understanding the multiphysics process involved in microwave heating (Chen et al., 2008; Geedipalli et al., 2007; Pitchai et al., 2012).

Submitted for review in July 2013 as manuscript number FPE 10314; approved for publication by the Food \& Process Engineering Institute of ASABE in October 2013.

The authors are Jiajia Chen, ASABE Member, Graduate Student, and Krishnamoorthy Pitchai, ASABE Member, Graduate Student, Department of Biological Systems Engineering, University of Nebraska, Lincoln, Nebraska; Sohan Birla, ASABE Member, Principal Research Scientist, and Ricardo Gonzalez, Senior Principal Research Scientist ConAgra Foods, Inc., Omaha, Nebraska; David Jones, ASABE Member, Professor and Associate Dean, and Jeyamkondan Subbiah, ASABE Member, Kenneth E. Morrison Distinguished Professor of Food Engineering, Departments of Biological Systems Engineering and Food Science and Technology, University of Nebraska, Lincoln, Nebraska. Corresponding author: Jeyamkondan Subbiah, 212 L.W. Chase Hall, University of Nebraska, Lincoln, NE 68583-0726; phone: 402-472-4944; e-mail: jeyam.subbiah@unl.edu.
For validating the performance of a microwave and heat transfer model, suitable foods and accurate information on their properties are necessary.

Whey protein gel has been used for validating microwave heat transfer models, as its properties match those of meat products (Tang et al., 2008; Wang et al., 2009a). Whey protein gel can easily be used to create different shapes and sizes to imitate the physical characteristics of meat foods (Tang et al., 2008). It can also be formulated to match meat foods in its dielectric and thermal properties, which are critical parameters influencing microwave heating. Mashed potato is a popular side dish served in restaurants and homes. In microwave heating, mashed potato is often used for model validation (Burfoot et al., 1996; Campañone and Zaritzky, 2005) because of its simple preparation, consistent chemical composition, and relatively homogeneous structure (Guan et al., 2004).

The dielectric and thermal properties of foods are important parameters that influence microwave heating. These properties, along with the characteristics of electromagnetic fields, determine the absorption of microwave energy and consequent heating behavior of food materials in microwave heating (Datta and Anantheswaran, 2001). Relative permittivity, the main dielectric property, is a complex quantity, which is defined as:

$$
\varepsilon=\varepsilon^{\prime}-j \varepsilon^{\prime \prime}
$$

where the real component is the dielectric constant $\left(\varepsilon^{\prime}\right)$, the imaginary component is the dielectric loss factor $\left(\varepsilon^{\prime \prime}\right)$, and $j=\sqrt{-1}$. The dielectric constant is related to the capacitance of a substance and its ability to store electric energy, 
while the loss factor determines the ability of the material to dissipate electric energy as heat (Ryynänen, 1995). Generally, the dielectric properties of food materials vary with composition, moisture, temperature, frequency, and storage time (Ryynänen, 1995; Sosa-Morales et al., 2010). Several researchers have measured the dielectric properties of various food products, such as salmon fillets (Wang et al., 2008), chicken breast muscle (Zhuang et al., 2007), egg whites and whole eggs (Wang et al., 2009b), hen eggs (Ragni et al., 2007), whey protein gel (Nelson and Bartley, 2000; Wang et al., 2003), fruits and vegetables (Guo et al., 2011; Tran et al., 1984), grape juice and wine (García et al., 2004), macaroni and cheese dinner preparation, ground whole-wheat flour, and apple juice (Nelson and Bartley, 2000, 2002). However, most of the food samples were measured only in the thawed state. The properties in the frozen temperature range are needed to simulate microwave heating of frozen food. Much of the reported data on food dielectric properties, obtained by coaxial probe methods, were collected after calibrating the measurement system with the standard calibration protocol (room temperature air, short circuit, and water). Because of the thermal expansion or contraction of the coaxial cable and probe, the measurement accuracy is compromised when the dielectric properties are measured at temperatures far from the calibration temperature. These errors, primarily attributed to temperature variation, can be eliminated by calibrating the system at multiple temperatures (Agilent, 2002).

Thermal properties (thermal conductivity and specific heat capacity) are also important input parameters for a heat transfer model. During heating and standing time, the thermal conductivity will influence the diffusion of thermal energy from hot spots to cold spots (Ayappa et al., 1991). In the microwave heating process, the specific heat capacity of food influences the heating rate. Especially for frozen samples, the latent heat associated with phase change will greatly influence the thawing process (Basak and Ayappa, 2001).

The objectives of this study are: (1) to determine temperature-dependent dielectric properties using a coaxial line method after multipoint temperature calibration, and (2) to determine thermal properties (thermal conductivity and specific heat capacity) of whey protein gel and mashed potato.

\section{MATERIALS AND MethodS}

\section{SAMPLES}

Whey protein gel was prepared by dissolving $20 \%$ whey protein powder $(80 \%$ concentrate, Davisco Foods International, Inc., Eden Prairie, Minn.), $0.56 \% \mathrm{CaCl}_{2}$, and $0.5 \%$ guar gum (guar NT, TIC Gums, White Marsh, Md.) in deionized water. The $\mathrm{CaCl}_{2}$ was added to adjust the dielectric properties of the whey protein gel, which would simulate meat products. The guar gum was added to improve the water-holding ability of the whey protein gel. The solution was stirred for $1.5 \mathrm{~h}$ for complete dispersion of the whey protein powder. The solution was poured into a $22 \mathrm{~mm}$ diameter copper tube and kept at $90^{\circ} \mathrm{C}$ in a conventional oven for $1.5 \mathrm{~h}$ to form a firm gel. The overall moisture content in the prepared whey protein gel was $80 \%$ (wet basis). The whey protein gel was then stored at $4{ }^{\circ} \mathrm{C}$ in a refrigerator until used for measurement of dielectric and thermal properties. The products were stored in the refrigerator for less than three days to minimize the effect of storage time on the properties.

Mashed potato was made of $23.8 \%$ mashed potato flakes (Real Premium mashed potato, Idahoan Foods, Lewisville, Ida.), 18.6\% whole milk (Prairieland Dairy whole milk, Prairieland Foods, Hallam, Neb.), 53.5\% deionized water, and $4.1 \%$ margarine (Great Value margarine, Wal-Mart Stores, Inc., Bentonville, Ark.) by weight basis. No additional salt was added to the mashed potato. The water and milk were heated to $50^{\circ} \mathrm{C}$ on a hot plate with stirring. The margarine was sliced into small pieces and gradually added into the hot solution. Once the margarine was dissolved in the solution, the uniform solution was poured into a mixing bowl containing mashed potato flakes. The mixture was then stirred for 5 min using a mechanical stirrer to make the sample homogeneous. The overall salt and moisture contents in the prepared mashed potato were $0.4 \%$ and $74 \%$ (wet basis), respectively. The mashed potato sample was stored at $4{ }^{\circ} \mathrm{C}$ in a refrigerator until used for measurement of dielectric and thermal properties.

\section{Dielectric Properties Measurement}

The dielectric properties were measured with an openended coaxial probe in the frequency range of 300 to $3000 \mathrm{MHz}$ at $5 \mathrm{MHz}$ intervals from $-20^{\circ} \mathrm{C}$ to $100^{\circ} \mathrm{C}$. The dielectric properties measurement system consisted of an impedance analyzer (RF E4991A, Agilent Technologies, Santa Clara, Cal.), a high-temperature coaxial cable, a micro-climatic chamber (MCBH 1.2, Cincinnati Sub-Zero Products, Inc., Cincinnati, Ohio), a high-temperature probe (85070E, Agilent Technologies), and a metal sample holder, as shown in figure 1 . Before calibrations and measurements, the impedance analyzer was switched on for at least 30 min to warm up, as recommended by the manufacturer. First, the impedance analyzer was calibrated by using air, short circuit, and a $50 \Omega$ load. The high-temperature probe was then connected to the impedance analyzer through a high-temperature coaxial cable. The probe was calibrated with air, short circuit, and deionized water (Wang et al., 2009b). During the probe calibration, the probe, sample holder, and short were all placed inside the micro-climatic chamber to maintain them at the specific calibration temperature. The high-temperature coaxial cable is made of stainless steel. Part of the high-temperature cable (about $20 \%$ of its length) and the test sample holder were kept in the chamber and were maintained at specific temperatures for calibration and measurement. This setup minimized the temperature differences between the probe and the food sample. About $20 \%$ of the cable length was exposed to the specific temperature inside the chamber, while the remaining cable was exposed to ambient temperature. The errors introduced due to temperature differences along the cable are negligible, based on our discussions with the manufacturer.

A custom-designed cylindrical test cell $(22 \mathrm{~mm}$ inner diameter and $120 \mathrm{~mm}$ length) made of stainless steel was 


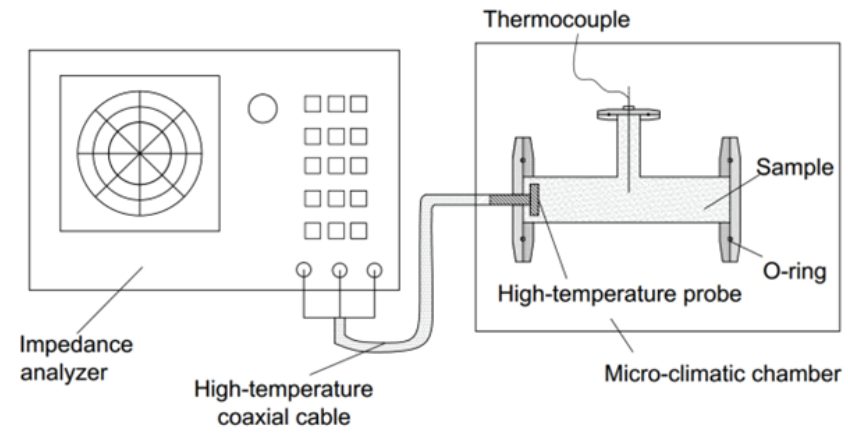

Figure 1. Schematic of dielectric properties measurement system.

used to control and maintain the sample temperature during the measurements. The sample size met Agilent's recommendation that the sample diameter be greater than $20 \mathrm{~mm}$ and the thickness be greater than $20 / \sqrt{\left|\varepsilon_{r}^{*}\right|} \mathrm{mm}$, where $\varepsilon_{r}{ }^{*}$ is the relative permittivity of the sample (Agilent, 2011).

The dielectric properties were measured from $-20^{\circ} \mathrm{C}$ to $0^{\circ} \mathrm{C}$ at $5^{\circ} \mathrm{C}$ intervals and from $0^{\circ} \mathrm{C}$ to $100^{\circ} \mathrm{C}$ at $10^{\circ} \mathrm{C}$ intervals. The results are reported at four typical temperatures, frozen, room, warm, and hot $\left(-20^{\circ} \mathrm{C}, 20^{\circ} \mathrm{C}, 50^{\circ} \mathrm{C}\right.$, and $100^{\circ} \mathrm{C}$ ), as a function of frequency and at key microwave frequencies (915 and $2450 \mathrm{MHz}$ ) as a function of temperature.

\section{VALIDATION OF CALIBRATION FOR DIELECTRIC Properties Measurement}

Three known standards (air, short circuit, and deionized water) were used to calibrate the probe. Even after calibration, there are potential additional sources of error, such as cable stability, air gaps, and sample thickness, that can affect the accuracy of the measurement. Methanol was used to validate the accuracy of calibration at room temperature for frequency-dependent dielectric properties measurement. The published data curves were values calculated by using the Debye equation (Debye, 1929) and relaxation parameter values for methanol given by Agilent (2006):

$$
\varepsilon=\varepsilon_{\infty}+\frac{\varepsilon_{S}-\varepsilon_{\infty}}{1+j \omega \tau}
$$

The values of $\varepsilon^{\prime}$ and $\varepsilon^{\prime \prime}$ can be calculated by equations 3 and 4, respectively:

$$
\begin{aligned}
& \varepsilon^{\prime}=\varepsilon_{\infty}+\frac{\varepsilon_{s}-\varepsilon_{\infty}}{1+\omega^{2} \tau^{2}} \\
& \varepsilon^{\prime \prime}=\frac{\left(\varepsilon_{s}-\varepsilon_{\infty}\right) \omega \tau}{1+\omega^{2} \tau^{2}}
\end{aligned}
$$

where $\varepsilon_{\infty}$ is the permittivity at the high-frequency limit, $\varepsilon_{s}$ is the low-frequency permittivity, and $\tau$ is the characteristic relaxation time of the medium. The following parameters were used in the Debye equation for methanol: $\varepsilon_{s}=$ 33.7, $\varepsilon_{\infty}=4.45$, and $\tau=4.95 \times 10^{-11} \mathrm{~s}$ (Agilent, 2006).

For temperature-dependent dielectric properties measurement, the measurement accuracy may be compromised when the dielectric properties are measured at temperatures far from the calibration temperature. Therefore, multipoint temperature calibrations $\left(1^{\circ} \mathrm{C}, 25^{\circ} \mathrm{C}, 40^{\circ} \mathrm{C}, 55^{\circ} \mathrm{C}, 70^{\circ} \mathrm{C}\right.$, and $85^{\circ} \mathrm{C}$ ) were performed to minimize errors. The number of temperature data points and the selection of calibration temperatures were determined by comparing measured values with published values for deionized water (Kaatze, 1989; Risman and Wäppling-Raaholt, 2007). Relative error, a percentage deviation of measured values from published values at each temperature, was determined to assess the validity of calibration for the range of temperatures for calibration at specific temperatures. Once the calibration method was developed, the temperature-dependent dielectric properties of whey protein gel and mashed potato were measured.

\section{Penetration Depth}

The microwave field intensity decays as the wave propagates into the material. Penetration depth is usually defined as the distance at which the power drops to $36.8 \%$ of its value at the surface of the material. It is an important concept to evaluate whether an electromagnetic field at a certain frequency can provide relatively uniform heating in a given food product (Zhu et al., 2012a). The penetration depth $\left(D_{p}\right)$ can be calculated as (Metaxas and Meredith, 1983):

$$
D_{p}=\frac{c}{2 \pi f \sqrt{2 \varepsilon^{\prime}\left[\sqrt{1+\left(\frac{\varepsilon^{\prime \prime}}{\varepsilon^{\prime}}\right)^{2}-1}\right]}}
$$

where $\varepsilon^{\prime}$ and $\varepsilon^{\prime \prime}$ are the dielectric constant and dielectric loss factor of the food sample, $c$ is the speed of light in free space $\left(3 \times 10^{8} \mathrm{~m} \mathrm{~s}^{-1}\right)$, and $f$ is the frequency of microwaves $(\mathrm{Hz})$. The above relationship is valid for plane wave incidence to the food surface. In a real microwave oven, the plane wave assumption is not valid. Despite the invalid assumption, this relationship shows the relative variation in penetration depth as a function of frequency, dielectric properties, and temperature and can serve as a guide for food product development. For that purpose, the penetration depth of whey protein gel and mashed potato are reported as a function of frequency at selected temperatures (frozen, room, warm, and hot).

\section{Thermal Properties Measurement}

Thermal conductivity was measured with a thermal properties analyzer (KD-2 Pro, Decagon Devices, Inc., Pullman, Wash.) connected with a single-needle (TR-1 $10 \mathrm{~cm}$ sensor) (Shamsudin et al., 2005). The accuracy of this apparatus is $\pm 10 \%$. Both the whey protein gel sample and mashed potato sample formed in cylindrical tubes (3.5 cm diameter and $12 \mathrm{~cm}$ height) were kept in the microclimatic chamber. The thermal conductivity was measured from $-20^{\circ} \mathrm{C}$ to $-5^{\circ} \mathrm{C}$ with intervals of $5^{\circ} \mathrm{C}$ and from $10^{\circ} \mathrm{C}$ to $80^{\circ} \mathrm{C}$ with intervals of $10^{\circ} \mathrm{C}$. The temperatures of the samples were controlled by the micro-climatic chamber.

The specific heat capacities of whey protein gel and 
mashed potato were measured with a differential scanning calorimeter (DSC 822, Mettler Toledo, Columbus, Ohio) from $-20^{\circ} \mathrm{C}$ to $120^{\circ} \mathrm{C}$ at a heating rate of $2^{\circ} \mathrm{C} \mathrm{min}^{-1}$ (Santos et al., 2005). About $10 \mathrm{mg}$ of food sample was placed in a $40 \mu \mathrm{L}$ dish (Al-crucibles) and covered with a lid. The dishes with samples and a reference were placed in the DSC for measurement. Liquid nitrogen was used to control the frozen temperature. All measurements were performed in triplicate, and the means of the three measurements are reported.

\section{RESULTS AND DISCUSSION \\ Frequency-Dependent Dielectric Properties MEASUREMENT: VALIDATION OF CALIBRATION}

Figure 2 shows a comparison of the measurements of frequency-dependent dielectric constant and loss factor of methanol at room temperature $\left(25^{\circ} \mathrm{C}\right)$ with the hightemperature probe. As shown in figure 2, the measured values of dielectric properties showed a good match with the published values. The root mean square error (RMSE) of dielectric constant and dielectric loss factor was 0.15 and 0.18 , respectively. Therefore, the $25^{\circ} \mathrm{C}$ calibration with three known standards (air, short circuit, and deionized water) is valid for frequency-dependent dielectric properties measurement at room temperature.

\section{Temperature-Dependent Dielectric Properties MEASUREMENT: VALIDATION OF CALIBRATION}

Multipoint temperature calibrations $\left(1^{\circ} \mathrm{C}, 25^{\circ} \mathrm{C}, 40^{\circ} \mathrm{C}\right.$, $55^{\circ} \mathrm{C}, 70^{\circ} \mathrm{C}$, and $85^{\circ} \mathrm{C}$ ) were performed to minimize errors. Water is one of the calibration standards. After multipoint temperature calibration, achieving reliable values for the dielectric properties of water that are close to the published values does not completely validate the multipoint temperature calibration for a wide range of dielectric materials. However, since most food materials have high water content, water is a good material for checking the validity of the multipoint temperature calibration and the accuracy of the measurements.

At $-5^{\circ} \mathrm{C}$, the measured dielectric constant and loss factor were 3.5 and 0.08 , respectively, for both calibration tem-

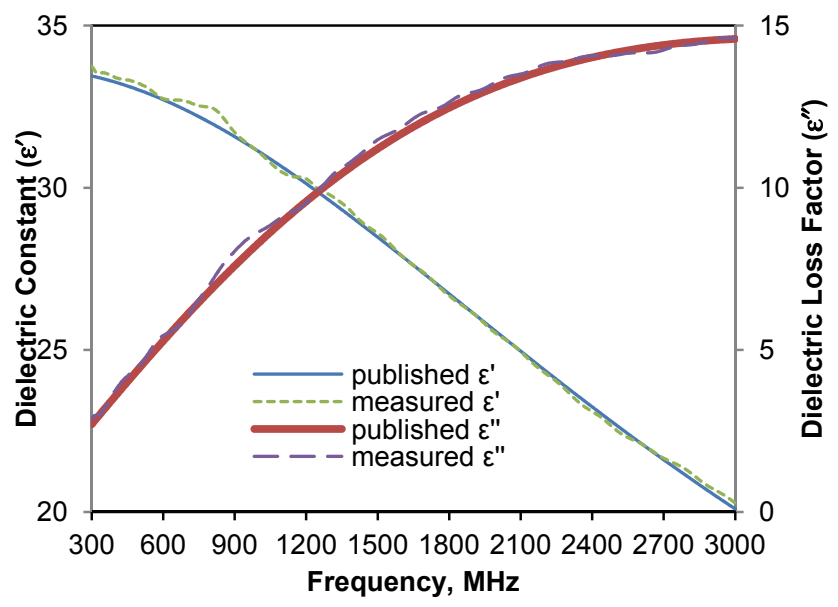

Figure 2. Comparison of measured and published values of dielectric constant and loss factor of methanol at $25^{\circ} \mathrm{C}$ (Agilent, 2006). peratures of $1^{\circ} \mathrm{C}$ and $25^{\circ} \mathrm{C}$, which means that the calibration at $25^{\circ} \mathrm{C}$ can be used for dielectric properties measurement in the frozen temperature range. For temperatures above $0^{\circ} \mathrm{C}$, the relative errors of dielectric properties of different temperature calibrations at $2450 \mathrm{MHz}$ are shown in figure 3 . The relative errors of dielectric constants calibrated at multipoint temperatures were generally within $\pm 5 \%$, which can be attributed to probe measurement error (Agilent, 2011). However, the measured dielectric loss factor showed a trend of increasing divergence as the temperatures increased from the calibration temperature. The maximum relative error of calibration at $25^{\circ} \mathrm{C}$ was $33 \%$ at $90^{\circ} \mathrm{C}$. The higher relative errors at higher temperature can be attributed to the errors when the calibration was done at room temperature. However, the relative errors decreased greatly when the high-temperature probe was calibrated near the temperatures of measurement. The relative error of dielectric loss factor of water at $2450 \mathrm{MHz}$ measured at $90^{\circ} \mathrm{C}$ decreased from $33 \%$ to $12 \%$ when the dielectric properties measurement system was calibrated at $85^{\circ} \mathrm{C}$. Although multipoint temperature calibration did not completely correct for measurement errors, it is a promising method for more accurate measurement of temperaturedependent dielectric properties.

A comparison of the dielectric properties of deionized water between measured (calibrated at $25^{\circ} \mathrm{C}$ and $85^{\circ} \mathrm{C}$ ) and published values at $2450 \mathrm{MHz}$ is shown in figure 4. Although higher relative errors are shown at higher temperatures, the measured dielectric properties are close to the published values. The large relative errors can be attributed to the low dielectric loss factor values of deionized water at higher temperatures. The relative errors of dielectric loss factors at $915 \mathrm{MHz}$ showed a trend similar to those at $2450 \mathrm{MHz}$ but were approximately twice as large. This is because the dielectric loss factor of deionized water at $915 \mathrm{MHz}$ is about half that at $2450 \mathrm{MHz}$. Figure 4 also clearly shows that calibration at two temperatures $\left(25^{\circ} \mathrm{C}\right.$ and $85^{\circ} \mathrm{C}$ ) is sufficient for measuring temperaturedependent dielectric properties from frozen to hot temperatures. Therefore, $25^{\circ} \mathrm{C}$ and $85^{\circ} \mathrm{C}$ calibration temperatures were used for measurement of dielectric properties of whey protein gel and mashed potato.

\section{Dielectric Constants of Whey Protein Gel and Mashed Potato}

The dielectric constant of whey protein gel and mashed potato from 300 to $3000 \mathrm{MHz}$ at four typical temperatures of $-20^{\circ} \mathrm{C}, 20^{\circ} \mathrm{C}, 50^{\circ} \mathrm{C}$ and $100^{\circ} \mathrm{C}$ (frozen, room, warm, and hot) are shown in figures 5 and 6 , respectively (values for $20^{\circ} \mathrm{C}$ and $20^{\circ} \mathrm{C}$ shown here were taken with calibration at $25^{\circ} \mathrm{C}$, and values for $50^{\circ} \mathrm{C}$ and $100^{\circ} \mathrm{C}$ were taken with calibration at $85^{\circ} \mathrm{C}$ ). At all temperatures, values of dielectric constant decreased as frequency increased. Minor fluctuations in dielectric properties were observed at around $1200 \mathrm{MHz}$ for whey protein gel and mashed potato, especially at higher temperatures $\left(50^{\circ} \mathrm{C}\right.$ and $\left.100^{\circ} \mathrm{C}\right)$ (figs. 5,6 , 8 , and 9), while this fluctuation was not observed in liquids (e.g., methanol in fig. 2). This may be due to the disturbance in connecting the test cell to the probe and to the contact of the food surface to the probe. After calibrating with 


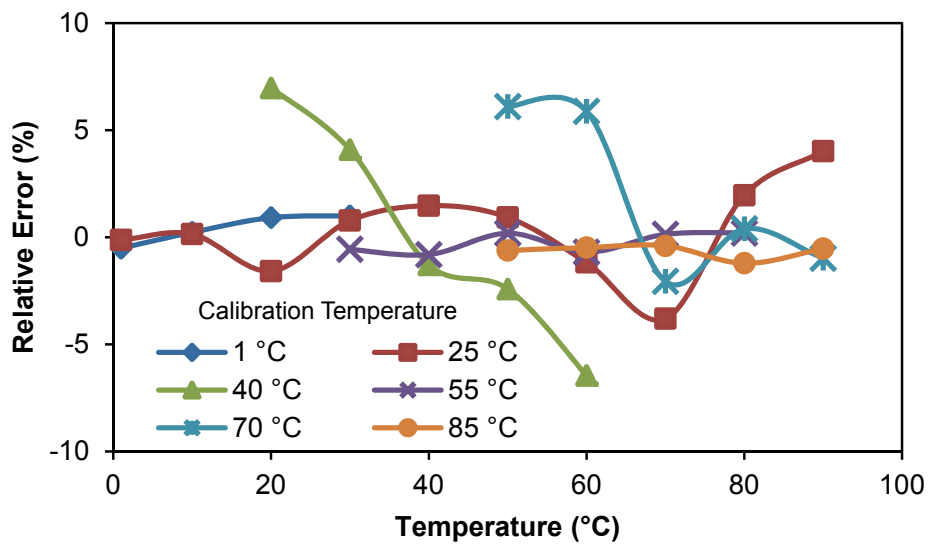

(a) Dielectric constant

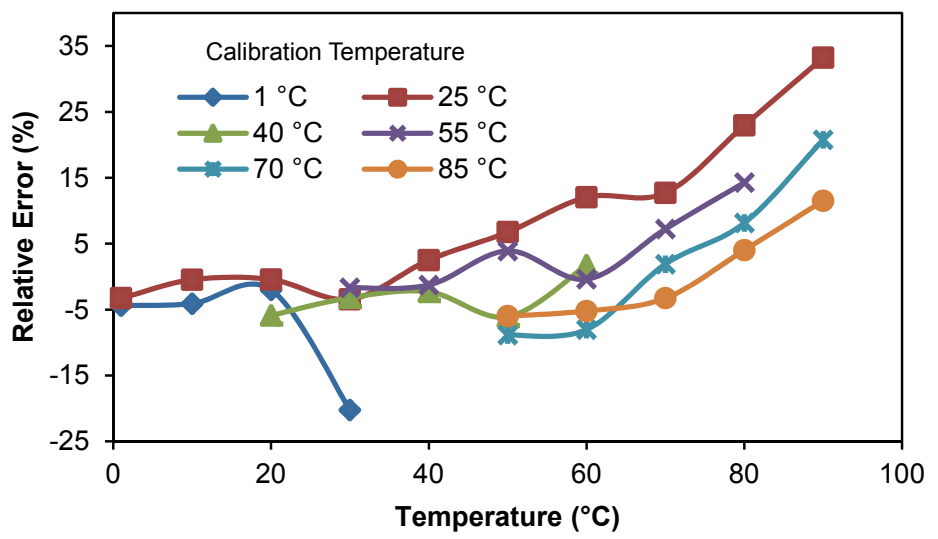

(b) Dielectric loss factor

Figure 3. Relative errors of (a) dielectric constant and (b) dielectric loss factor of deionized water calibrated at multipoint temperatures compared with published values at $2450 \mathrm{MHz}$ (Kaatze, 1989; Risman and Wäppling-Raaholt, 2007).

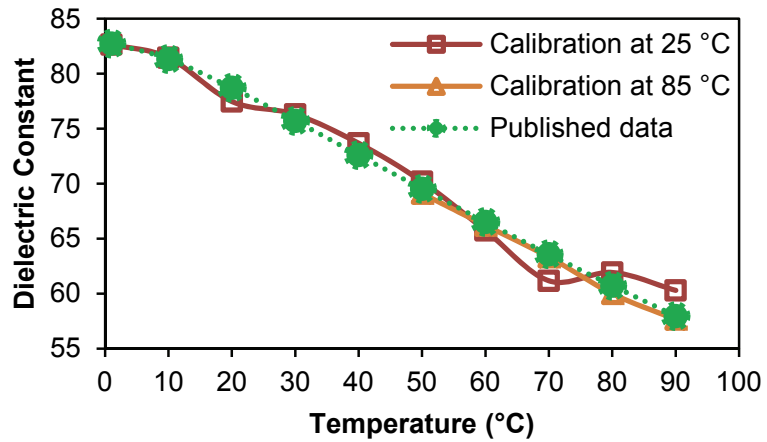

(a) Dielectric constant

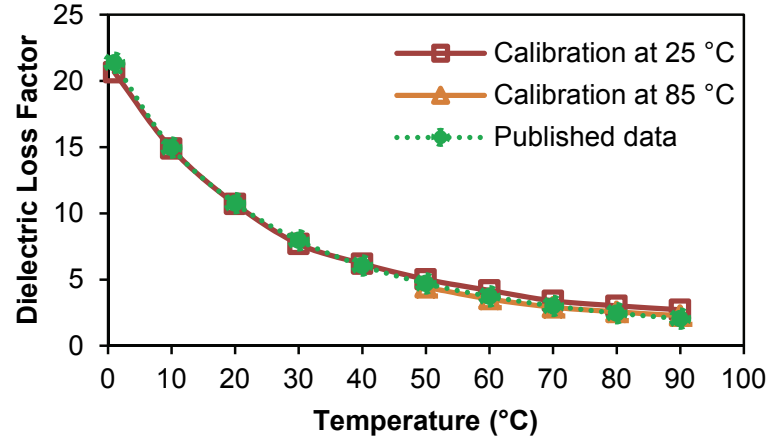

(b) Dielectric loss factor

Figure 4. Comparison of (a) dielectric constant and (b) dielectric loss factor of deionized water between calibrated at $25^{\circ} \mathrm{C}$ and $85^{\circ} \mathrm{C}$ and published values at $2450 \mathrm{MHz}$ (Kaatze, 1989; Risman and Wäppling-Raaholt, 2007).

water, the test cell was removed and emptied. For measuring the dielectric properties of liquids, the empty test cell was connected with ease, and therefore disturbance to the probe was minimal. The liquid sample, such as water or methanol, was then poured into the test cell, and there was good contact of the probe with the sample. For measuring the dielectric properties of solids, the test cell was filled with sample and then connected to the probe. During con- nection, some disturbance occurred on the probe end. In addition, the manufacturer recommends that the sample surface be as flat as the probe face, with surface aberrations less than 2.5 microns (Agilent, 2011). At higher temperatures, some moisture may evaporate at the contact surface of the food with the probe. The generated vapor pressure at the contact surface may compromise the flat surface requirement of the sample. Thus, we observed slight fluctua- 


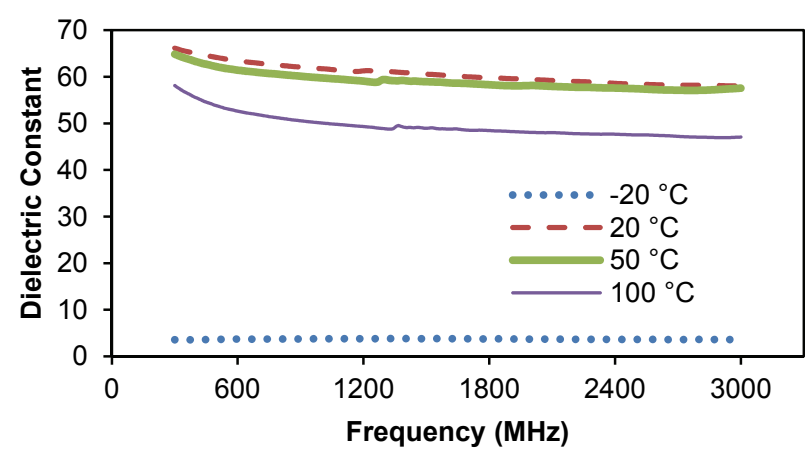

Figure 5. Frequency dependence of dielectric constant of whey protein gel at indicated temperatures.

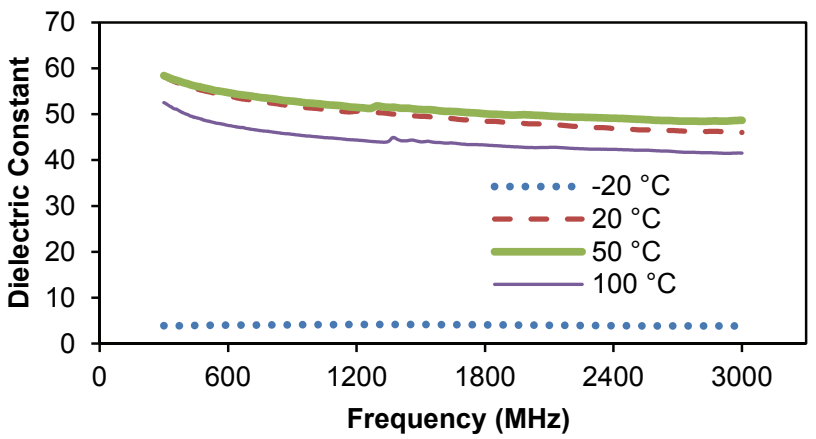

Figure 6. Frequency dependence of dielectric constant of mashed potato at indicated temperatures.

tion in values of dielectric properties of solid samples at higher temperatures. Similar minor fluctuations in dielectric data were found in the literature for various products, such as chestnut flour (Zhu et al., 2012b), fruit juices (Zhu et al., 2012a), and soy flour (Terigar et al., 2010). For both whey protein gel and mashed potato, the dielectric constant values of frozen samples were much lower than those of room, warm, and hot temperature samples.

The temperature dependence of the dielectric constants of whey protein gel and mashed potato at $2450 \mathrm{MHz}$ is shown in figure 7 . For both food samples, in the frozen temperature range, the dielectric constant increased rapidly from the lowest values at the frozen state to the highest values at the thawed state. The dielectric constant values of whey protein gel and mashed potato increased from the lowest value of around 3.5 and 3.8 , respectively, at $-20^{\circ} \mathrm{C}$ to the highest values of 59.5 and 47.6 , respectively, at $0^{\circ} \mathrm{C}$, where the samples were thawed. At higher temperatures, the dielectric constants of whey protein gel and mashed potato decreased linearly as the temperature increased from $0^{\circ} \mathrm{C}$ to $100^{\circ} \mathrm{C}$ for both calibration temperatures. The dielectric constants of whey protein gel measured with calibration at $25^{\circ} \mathrm{C}$ showed a small difference from the measured values with $85^{\circ} \mathrm{C}$ calibration at higher temperatures, especially from $80^{\circ} \mathrm{C}$ to $90^{\circ} \mathrm{C}$. At higher temperatures, the dielectric constants measured with $85^{\circ} \mathrm{C}$ calibration showed better linearity. Therefore, it is recommended that $25^{\circ} \mathrm{C}$ calibration be used for measuring dielectric properties at temperatures less than $50^{\circ} \mathrm{C}$, and $85^{\circ} \mathrm{C}$ calibration be used for measuring dielectric properties at temperatures greater than or equal to $50^{\circ} \mathrm{C}$. A similar trend was also observed at $915 \mathrm{MHz}$.

The dielectric properties of materials are governed by free water dispersion, bound water dispersion, and ionic conduction (Feng et al., 2002). The gradual decrease in the dielectric constant with increasing temperature appears to be reasonable for food samples containing $70 \%$ to $80 \%$ water, which is dominated by free water dispersion and ionic conduction (Feng et al., 2002).

\section{Dielectric Loss Factors of Whey Protein Gel and Mashed Potato}

The dielectric loss factors of whey protein gel and mashed potato from 300 to $3000 \mathrm{MHz}$ at temperatures of $20^{\circ} \mathrm{C}, 20^{\circ} \mathrm{C}, 50^{\circ} \mathrm{C}$, and $100^{\circ} \mathrm{C}$ are shown in figures 8 and 9 . Values for $-20^{\circ} \mathrm{C}$ and $20^{\circ} \mathrm{C}$ were taken with the $25^{\circ} \mathrm{C}$ calibration, and values for $50^{\circ} \mathrm{C}$ and $100^{\circ} \mathrm{C}$ were taken with the $85^{\circ} \mathrm{C}$ calibration. For both samples, the dielectric loss factor at room, warm, and hot temperatures rapidly decreased with frequency. For example, the dielectric loss factor of whey protein gel and mashed potato at $100^{\circ} \mathrm{C}$ decreased from 123.6 and 237.9, respectively, at $300 \mathrm{MHz}$ to 16.9 and 29.7 , respectively, at $3000 \mathrm{MHz}$. The values of frozen sample were nearly constant ( 0.1 to 0.3$)$ throughout the whole frequency range. The dielectric loss factor increased with

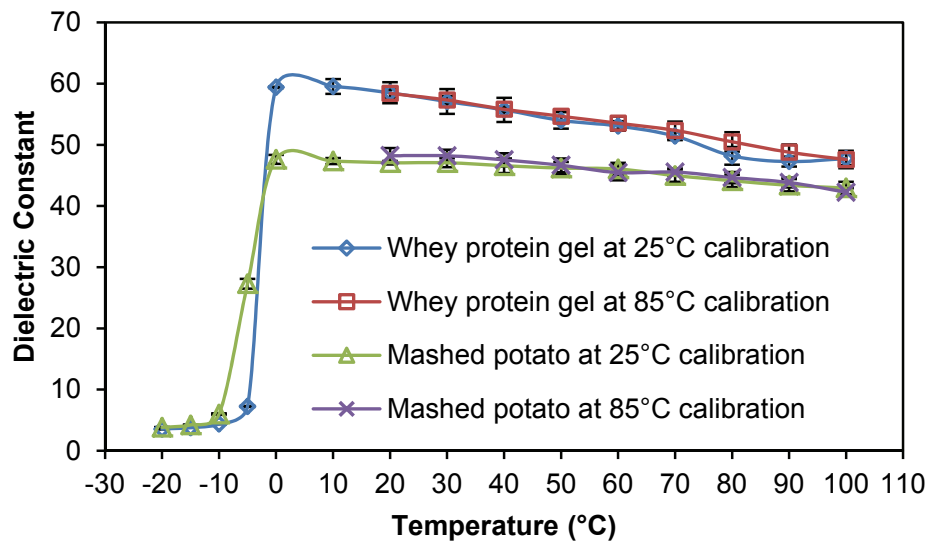

Figure 7. Temperature dependence of dielectric constant of whey protein gel and mashed potato at $2450 \mathrm{MHz}$. 


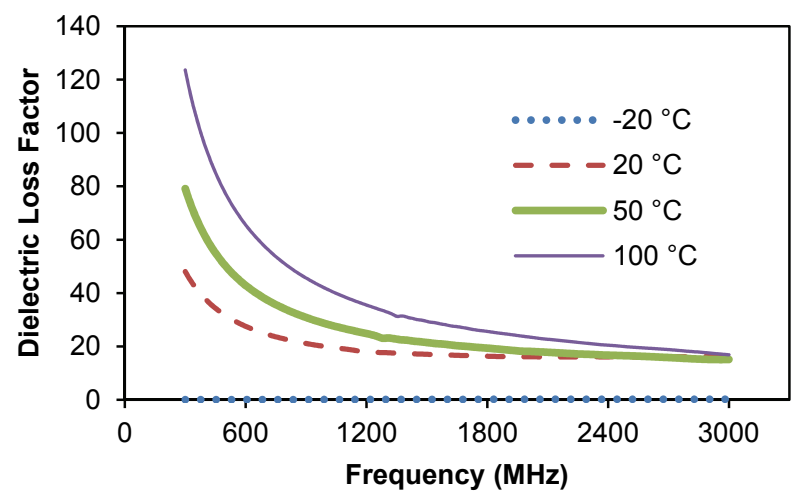

Figure 8. Frequency dependence of dielectric loss factor of whey protein gel at indicated temperatures.

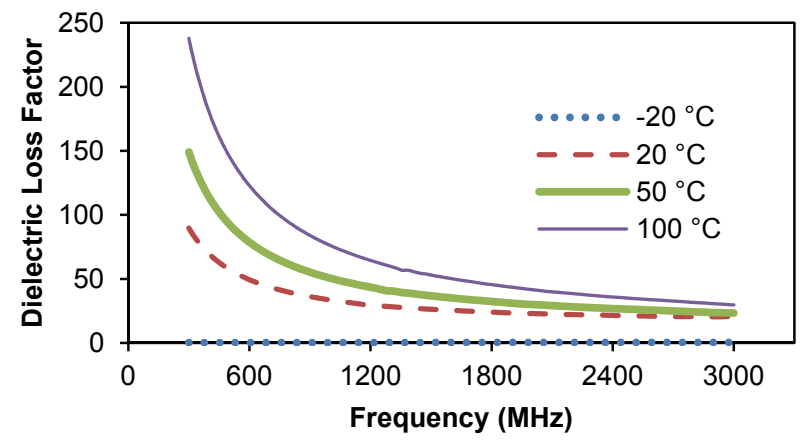

Figure 9. Frequency dependence of dielectric loss factor of mashed potato at indicated temperatures.

increasing temperature in the whole frequency range.

The dielectric loss factors of whey protein gel and mashed potato at $2450 \mathrm{MHz}$ increased generally with increasing temperature, as shown in figure 10 . From $-20^{\circ} \mathrm{C}$ to $0^{\circ} \mathrm{C}$, the dielectric loss factor of both samples rapidly increased. The dielectric loss factors of whey protein gel and mashed potato increased from the lowest values of about 0.2 and 0.4 , respectively, at $-20^{\circ} \mathrm{C}$ to about 20.7 and 22.1 , respectively, at $0^{\circ} \mathrm{C}$. The very low values of dielectric properties in the frozen temperature range can be attributed the rigid crystalline structure of ice, which influences the microwave power absorption of frozen food. Above $0^{\circ} \mathrm{C}$,
Table 1. Dielectric properties (means \pm 1 standard deviation) of whey protein gel and mashed potato at $915 \mathrm{MHz}$.

\begin{tabular}{cccccc}
\hline \multirow{2}{*}{$\begin{array}{c}\text { Temperature } \\
\left({ }^{\circ} \mathrm{C}\right)\end{array}$} & \multicolumn{2}{c}{ Whey Protein Gel } & & \multicolumn{2}{c}{ Mashed Potato } \\
\cline { 2 - 3 } \cline { 5 - 6 } & $\mathcal{\varepsilon}^{\prime}$ & $\mathcal{\varepsilon}^{\prime \prime}$ & & $\mathcal{\varepsilon}^{\prime}$ & $\varepsilon^{\prime \prime}$ \\
\hline-20 & $3.6 \pm 0.1$ & $0.1 \pm 0.0$ & & $4.1 \pm 0.0$ & $0.3 \pm 0.0$ \\
-15 & $4.0 \pm 0.1$ & $0.2 \pm 0.0$ & & $4.6 \pm 0.0$ & $0.6 \pm 0.0$ \\
-10 & $4.8 \pm 0.0$ & $0.6 \pm 0.0$ & & $6.8 \pm 0.0$ & $1.4 \pm 0.1$ \\
-5 & $8.3 \pm 0.2$ & $1.9 \pm 0.1$ & & $31.1 \pm 0.6$ & $15.7 \pm 0.9$ \\
0 & $65.9 \pm 0.4$ & $18.0 \pm 0.5$ & & $53.5 \pm 0.6$ & $25.3 \pm 0.9$ \\
10 & $63.8 \pm 0.8$ & $19.1 \pm 0.1$ & & $53.3 \pm 0.6$ & $29.8 \pm 0.2$ \\
20 & $62.0 \pm 1.5$ & $20.9 \pm 0.1$ & & $52.3 \pm 0.5$ & $34.5 \pm 1.2$ \\
30 & $60.2 \pm 1.8$ & $23.2 \pm 0.3$ & & $51.9 \pm 0.9$ & $40.1 \pm 1.0$ \\
40 & $58.7 \pm 1.8$ & $25.7 \pm 0.1$ & & $51.1 \pm 1.4$ & $45.8 \pm 0.2$ \\
50 & $57.4 \pm 0.4$ & $29.3 \pm 0.8$ & & $50.8 \pm 1.3$ & $50.1 \pm 0.7$ \\
60 & $56.3 \pm 0.8$ & $32.5 \pm 1.0$ & & $49.3 \pm 1.5$ & $54.5 \pm 0.4$ \\
70 & $55.1 \pm 1.2$ & $35.4 \pm 0.9$ & & $49.2 \pm 0.8$ & $62.0 \pm 0.3$ \\
80 & $53.2 \pm 1.4$ & $38.7 \pm 0.9$ & & $48.1 \pm 1.1$ & $70.2 \pm 0.5$ \\
90 & $51.6 \pm 1.1$ & $42.4 \pm 1.7$ & & $47.1 \pm 1.0$ & $77.8 \pm 0.9$ \\
100 & $50.5 \pm 1.2$ & $45.0 \pm 1.2$ & & $45.5 \pm 0.7$ & $82.7 \pm 2.4$ \\
\hline
\end{tabular}

the dielectric loss factors of both samples decreased slightly and then increased almost linearly with temperature. A slight decrease around the thawing temperature may be attributed to the structural changes of the samples due to phase change. From figures 7 and 10, it can be concluded that two temperature calibrations were sufficient. We recommend that calibration at $25^{\circ} \mathrm{C}$ be used to collect data from frozen to $40^{\circ} \mathrm{C}$ and calibration at $85^{\circ} \mathrm{C}$ be used to collect data from $50^{\circ} \mathrm{C}$ to $100^{\circ} \mathrm{C}$. Table 1 summarizes the dielectric data for whey protein gel and mashed potato at various temperatures at $915 \mathrm{MHz}$. Note that data were collected using the $25^{\circ} \mathrm{C}$ calibration for temperatures less than $50^{\circ} \mathrm{C}$, and $85^{\circ} \mathrm{C}$ calibration was used for temperatures greater than or equal to $50^{\circ} \mathrm{C}$.

Nelson and Bartley (2002) and Guan et al. (2004) measured the properties of whey protein gel and mashed potato from thawed condition to hot condition up to $1800 \mathrm{MHz}$, whereas our study measured from frozen condition to hot condition up to $3000 \mathrm{MHz}$ (which includes domestic microwave frequencies). Most importantly, we performed multipoint temperature calibration, which is critical for frozen and high temperatures, while previous studies performed only single-point temperature calibration. At $915 \mathrm{MHz}$, the trends of dielectric properties as a function of temperature found in this study agreed well with values reported in the literature. Ionic conduction is the dominant

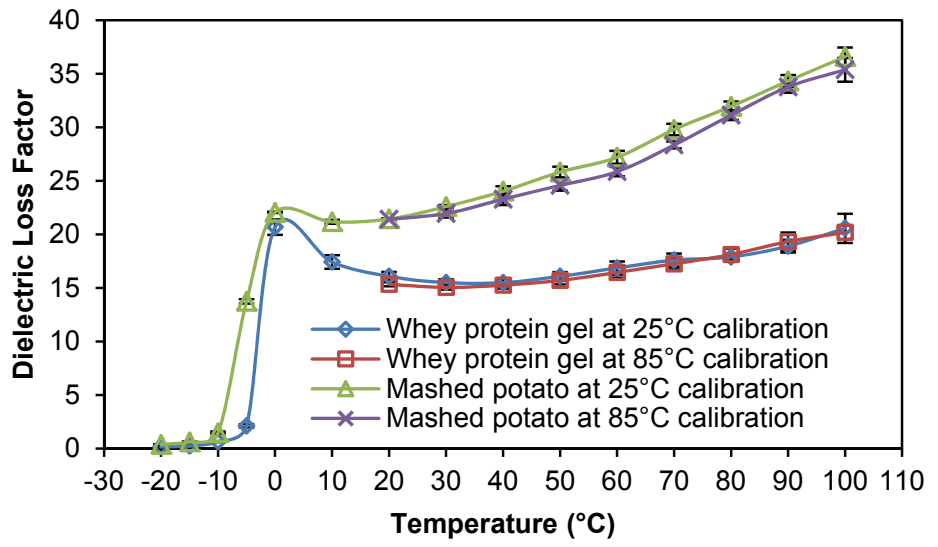

Figure 10. Temperature dependence of dielectric loss factor of whey protein gel and mashed potato at $2450 \mathrm{MHz}$. 
factor for dielectric loss factor at frequencies lower than about $1 \mathrm{GHz}$. Therefore, the increase in the loss factor is mainly attributed to the increase in ionic conduction (Nelson and Bartley, 2002) with increasing temperature at $915 \mathrm{MHz}$.

The dielectric loss factors of whey protein gel and mashed potato both showed a significant difference between frozen samples and room, warm, and hot samples at two typical microwave heating frequencies, which will greatly influence the microwave heating rate. The volumetric heating rate or the power deposition of microwaves $(Q)$ can be calculated as: $Q=2 \pi f \cdot \varepsilon_{0} \cdot \varepsilon^{\prime \prime} \cdot\left(E_{r m s}\right)^{2}$, where $f$ is the frequency of the microwaves, $\varepsilon_{0}$ is the permittivity of free space, $\varepsilon^{\prime \prime}$ is the dielectric loss factor of the material, and $E_{r m s}$ is the root mean square value of electric field intensity at a location (Liu et al., 2013). Therefore, the nonuniformity of the microwave heating rate is related not only to the electromagnetic field pattern but also to the spatial and temporal variation in food properties. For frozen food, the microwave heating rate is very slow because of the low dielectric loss factor. When some part of the frozen food is thawed, the dielectric loss factor of the thawed regions dramatically increases, and those regions can be heated quickly. This nonuniform heating phenomenon due to the loss factor is also similarly explained as "thermal runaway" (Zhu et al., 2012a). This phenomenon challenges the devel- opment of frozen foods for microwave heating with good cooking performance in terms of heating uniformity. Modeling of the microwave heating process based on measured dielectric and thermal properties is a powerful tool to assist food scientists in understanding how microwaves interact with various components of food and can allow them to design food products and packages that heat more uniformly in a wide range of microwave ovens. Accurate measurement of temperature-dependent properties is critical for accurate simulation by these models (Datta and Anantheswaran, 2001; Pitchai et al., 2012).

\section{Penetration Depth}

The penetration depth for whey protein gel and mashed potato at temperatures of $-20^{\circ} \mathrm{C}, 20^{\circ} \mathrm{C}, 50^{\circ} \mathrm{C}$, and $100^{\circ} \mathrm{C}$ from 300 to $3000 \mathrm{MHz}$, calculated from average values of dielectric constants and dielectric loss factors, are shown in figures 11 and 12, respectively. The penetration depths for both food samples decreased with increasing frequency and temperature, which showed good agreement with previously reported values for mashed potato (Guan et al., 2004) and Red Delicious apples (Feng et al., 2002). The penetration depth decreased rapidly at lower temperatures. For example, when the frequency increased from 300 to $3000 \mathrm{MHz}$, the penetration depth for whey protein gel decreased from 7546 to $154 \mathrm{~mm}$ at $-20^{\circ} \mathrm{C}$ and decreased from 12.7 to $6.6 \mathrm{~mm}$ at $100^{\circ} \mathrm{C}$.

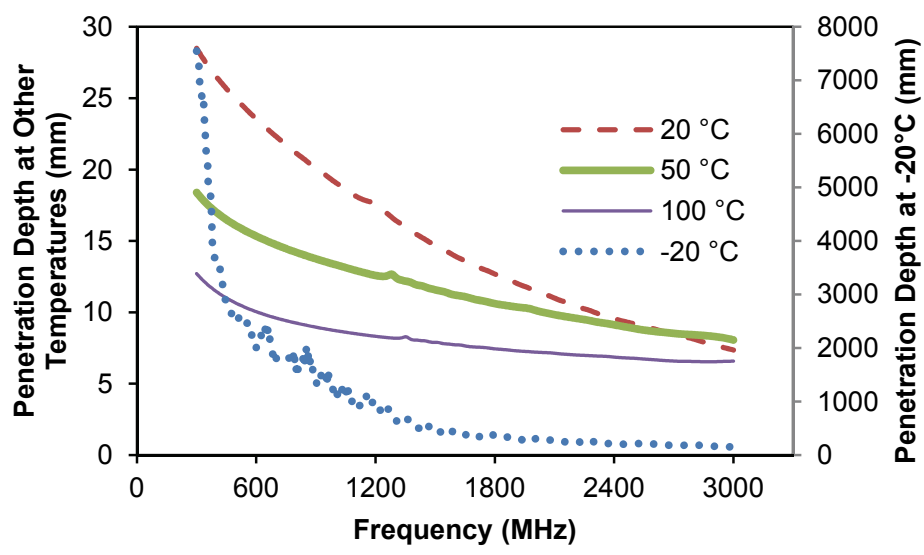

Figure 11. Calculated penetration depth of whey protein gel at indicated temperatures as a function of frequency from 300 to $3000 \mathrm{MHz}$.

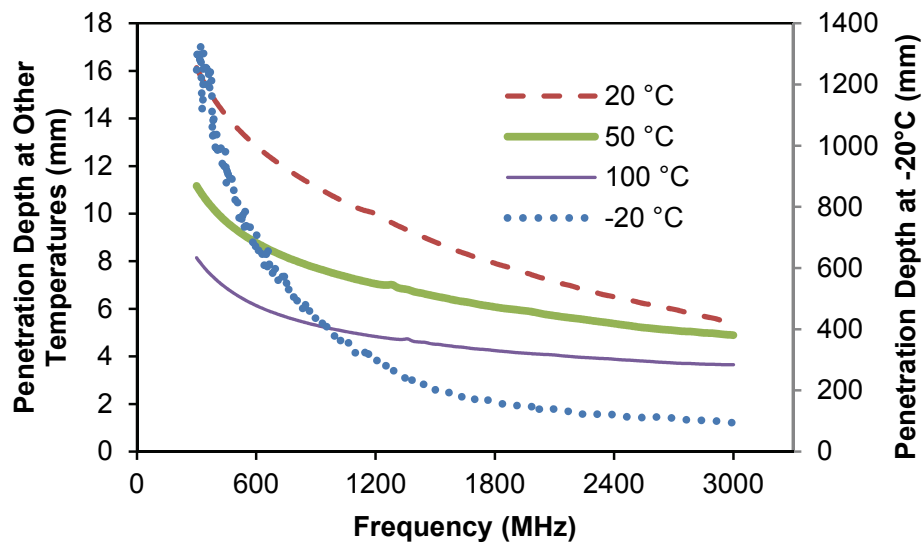

Figure 12. Calculated penetration depth of mashed potato at indicated temperatures as a function of frequency from 300 to $3000 \mathrm{MHz}$. 
At frozen temperatures $\left(-20^{\circ} \mathrm{C}\right)$, the penetration depth was fairly large $(203.8 \mathrm{~mm}$ for whey protein gel and $114.4 \mathrm{~mm}$ for mashed potato at $2450 \mathrm{MHz}$ ), while it dramatically decreased when the sample was thawed $(7.4 \mathrm{~mm}$ for whey protein gel and $6.1 \mathrm{~mm}$ for mashed potato at $2450 \mathrm{MHz}$ and $0^{\circ} \mathrm{C}$ ). The differences in penetration depth between the frozen and thawed states of the sample dramatically influenced the heating uniformity and caused runaway heating. Because of the low penetration depth at higher temperatures, edge heating may be severe. Therefore, the thickness of food materials should be considered in food design. For example, in pasteurization with radio-frequency or microwave energy, the thickness of food materials should be not more than two or three time the penetration depth (Schiffmann, 1995). For multicompartment frozen meals, it is ideal to vary the thickness of the food in each compartment depending on the dielectric properties of the product in that compartment so that the foods in all compartments are heated uniformly.

\section{Thermal CONDUCTIVITY}

The temperature-dependent thermal conductivities of whey protein gel and mashed potato are listed in table 2 . In the frozen temperature range, the thermal conductivity decreased with increasing temperature due to the decreasing ice fraction. In the thawed temperature range, the thermal conductivities did not change considerably. A similar trend was reported for thermal conductivity measurements of dough (Kumcuoglu et al., 2007), apples (Willix et al., 1998), potato starch, and gelatin (Miyawaki and Pongsawanit, 1994). The measured thermal conductivities of whey protein gel and mashed potato at thawing were close to the reported values for whey protein films (Tuladhar et al., 2002) and sweetpotato (Fasina et al., 2003), respectively. Whey protein gel and mashed potato both have slightly lower thermal conductivity values than those of ice and water (Sears et al., 1982), as whey protein gel and mashed potato contain about $70 \%$ to $80 \%$ water.

The thermal conductivity difference between frozen and thawed materials will influence the temperature distribution in food during microwave heating. The heating rate is lower in the frozen state because of lower dielectric properties.
Table 2. Thermal conductivity (means \pm 1 standard deviation) of whey protein gel and mashed potato.

\begin{tabular}{ccc}
\hline $\begin{array}{c}\text { Temperature } \\
\left({ }^{\circ} \mathrm{C}\right)\end{array}$ & \multicolumn{2}{c}{ Thermal Conductivity $\left(\mathrm{W} \mathrm{m}^{-1} \mathrm{~K}^{-1}\right)$} \\
\cline { 2 - 3 }-20 & $2.24 \pm 0.03$ & Mashed Potato \\
-15 & $2.15 \pm 0.00$ & $2.19 \pm 0.06$ \\
-10 & $2.12 \pm 0.00$ & $2.03 \pm 0.01$ \\
-5 & $2.03 \pm 0.06$ & $1.84 \pm 0.00$ \\
10 & $0.62 \pm 0.00$ & $1.67 \pm 0.01$ \\
20 & $0.62 \pm 0.01$ & $0.57 \pm 0.01$ \\
30 & $0.62 \pm 0.01$ & $0.59 \pm 0.01$ \\
40 & $0.62 \pm 0.01$ & $0.57 \pm 0.01$ \\
50 & $0.61 \pm 0.01$ & $0.58 \pm 0.00$ \\
60 & $0.64 \pm 0.01$ & $0.57 \pm 0.04$ \\
70 & $0.66 \pm 0.01$ & $0.59 \pm 0.01$ \\
80 & $0.67 \pm 0.05$ & $0.59 \pm 0.01$ \\
& & $0.59 \pm 0.01$ \\
\hline
\end{tabular}

After some part of the frozen sample is thawed, the heating rate increases in the thawed part because of the higher loss factor. However, the low thermal conductivity of the thawed layer will delay the heat transfer between the thawed and frozen materials. These phenomena cause the hot spots in the food to become hotter, which results in greater nonuniform heating.

\section{SPECIFIC HeAT CAPACITY}

The specific heat capacities of whey protein gel and mashed potato as a function of temperature from $-20^{\circ} \mathrm{C}$ to $120^{\circ} \mathrm{C}$ are shown in figure 13 . Whey protein gel and mashed potato both showed the same trend. From $-20^{\circ} \mathrm{C}$ to $-5^{\circ} \mathrm{C}$, the specific heat capacities of whey protein gel and mashed potato increased slightly from about 0.5 to $5.8 \mathrm{~kJ}$ $\mathrm{kg}^{-1}{ }^{\circ} \mathrm{C}^{-1}$ and from 0.9 to $9.4 \mathrm{~kJ} \mathrm{~kg}^{-1}{ }^{\circ} \mathrm{C}^{-1}$, respectively. From $-5^{\circ} \mathrm{C}$ to $10^{\circ} \mathrm{C}$, the specific heat capacities of the two samples increased sharply to peak values of 59.6 and $32.8 \mathrm{~kJ} \mathrm{~kg} \mathrm{k}^{-1}{ }^{\circ} \mathrm{C}^{-1}$, respectively, at temperature of $2.9^{\circ} \mathrm{C}$ and $1.6^{\circ} \mathrm{C}$ and then decreased sharply to bottom values of about 3.5 and $4.0 \mathrm{~kJ} \mathrm{~kg}^{-1}{ }^{\circ} \mathrm{C}^{-1}$, respectively, at temperatures of $8^{\circ} \mathrm{C}$ and $5^{\circ} \mathrm{C}$. This first peak in specific heat capacity represents the phase change from frozen to thawed state. By determining the area under the peak from $-5^{\circ} \mathrm{C}$ to $5^{\circ} \mathrm{C}$, the latent heat of fusion was determined as 219.1 and $186.8 \mathrm{~kJ}$ $\mathrm{kg}^{-1}$ for whey protein gel and mashed potato, respectively. After the phase change of melting, the specific heat capacities of whey protein gel and mashed potato both increased

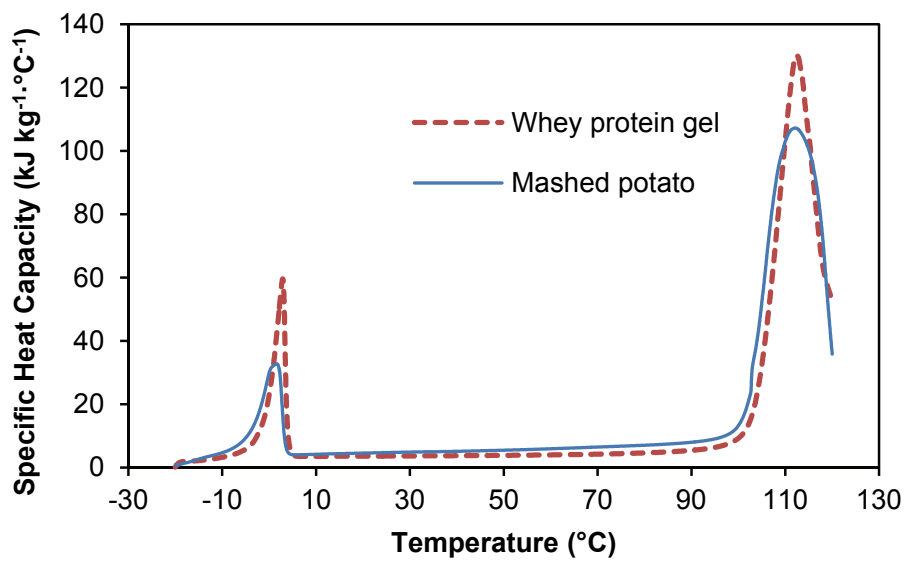

Figure 13. Specific heat capacity of whey protein gel and mashed potato. 
slowly until the temperature reached the second phase change of vaporization at around $100^{\circ} \mathrm{C}$. The latent heat of fusion and vaporization will delay the temperature rise during phase change. Both the latent heat of fusion and vaporization of water in whey protein gel are higher than those of mashed potato, which can be attributed to the higher moisture content of whey protein gel. This delay in temperature rise also influences the nonuniformity of heating during microwave heating of frozen food.

\section{Conclusions}

For accurate measurement of dielectric properties as a function of temperature, especially at frozen conditions, a measurement system and a multipoint temperature calibration protocol were developed. Enclosing the sample and the high-temperature probe in a microclimatic chamber was critical for accurate temperature control and accurate measurement of dielectric data at frozen temperatures. Calibrations at two temperatures $\left(25^{\circ} \mathrm{C}\right.$ and $\left.85^{\circ} \mathrm{C}\right)$ were sufficient to accurately measure the dielectric properties of foods from frozen to hot temperatures. At all temperatures, the dielectric constant and dielectric loss factor both decreased with increasing frequency. In the frozen temperature range, the dielectric properties rapidly increased with increasing temperature. At room, warm, and hot temperatures, the dielectric constant decreased linearly with temperature, while the dielectric loss factor decreased slightly and then increased linearly with temperature. The thermal conductivity of frozen samples was higher than that of room, warm, and hot temperature samples. The latent heat of fusion for whey protein gel and mashed potato was calculated as 219.1 and $186.8 \mathrm{~kJ} \mathrm{~kg}^{-1}$, respectively. These properties are critical input parameters for a microwave heat transfer model, which can be used by food scientists in developing novel food products that minimize nonuniform heating during cooking in domestic microwave ovens.

\section{ACKNOWLEDGEMENTS}

This study was sponsored by ConAgra Foods, Inc. Partial support for this study was provided by a USDACSREES NIFSI grant (Project No. 2008-51110-04340). The authors also thank the Chinese Scholarship Council for providing a partial scholarship to Jiajia Chen for his doctoral studies at the University of Nebraska-Lincoln.

\section{REFERENCES}

Agilent. 2002. Applying error correction to network analyzer measurements. Agilent Literature No. 5965-7709E. Santa Clara, Cal.: Agilent Technologies.

Agilent. 2006. Basics of measuring the dielectric properties of materials: Application note. Agilent Literature No. 59892589EN. Santa Clara, Cal.: Agilent Technologies.

Agilent. 2011. 85070E Dielectric probe kit $200 \mathrm{MHz}$ to $50 \mathrm{GHz}$ : Technical overview. Agilent Literature No. 5989-0222EN. Santa Clara, Cal.: Agilent Technologies.

Ayappa, K., H. Davis, E. Davis, and J. Gordon. 1991. Analysis of microwave heating of materials with temperature-dependent properties. AIChE J. 37(3): 313-322.
Basak, T., and K. Ayappa. 2001. Influence of internal convection during microwave thawing of cylinders. AIChE J. 47(4): 835850 .

Bradshaw, S., S. Delport, and E. Van Wyk. 1997. Qualitative measurement of heating uniformity in a multimode microwave cavity. J. Microwave Power and Electromag. Energy 32(2): 8895.

Burfoot, D., C. Railton, A. Foster, and S. Reavell. 1996. Modelling the pasteurisation of prepared meals with microwaves at 896 MHz. J. Food Eng. 30(1): 117-133.

Campañone, L. A., and N. E. Zaritzky. 2005. Mathematical analysis of microwave heating process. J. Food Eng. 69(3): 359-368.

Chen, H., J. Tang, and F. Liu. 2008. Simulation model for moving food packages in microwave heating processes using conformal FDTD method. J. Food Eng. 88(3): 294-305.

Datta, A. K., and R. C. Anantheswaran. 2001. Handbook of Microwave Technology for Food Applications. New York, N.Y.: Marcel Dekker.

Debye, P. 1929. Polar Molecules. New York, N.Y.: The Chemical Catalog Co.

Fasina, O., B. Farkas, and H. Fleming. 2003. Thermal and dielectric properties of sweetpotato puree. Intl. J. Food Properties 6(3): 461-472.

Feng, H., J. Tang, and R. Cavalieri. 2002. Dielectric properties of dehydrated apples as affected by moisture and temperature. Trans. ASAE 45(1): 129-136.

García, A., J. Torres, M. De Blas, A. De Francisco, and R. Illanes. 2004. Dielectric characteristics of grape juice and wine. Biosystems Eng. 88(3): 343-349.

Geedipalli, S., V. Rakesh, and A. Datta. 2007. Modeling the heating uniformity contributed by a rotating turntable in microwave ovens. J. Food Eng. 82(3): 359-368.

Guan, D., M. Cheng, Y. Wang, and J. Tang. 2004. Dielectric properties of mashed potatoes relevant to microwave and radiofrequency pasteurization and sterilization processes. J. Food Sci. 69(1): 30-37.

Gunasekaran, S., and H.-W. Yang. 2007. Effect of experimental parameters on temperature distribution during continuous and pulsed microwave heating. J. Food Eng. 78(4): 1452-1456.

Guo, W., X. Zhu, S. O. Nelson, R. Yue, H. Liu, and Y. Liu. 2011. Maturity effects on dielectric properties of apples from 10 to 4500 MHz. LWT - Food Sci. and Tech. 44(1): 224-230.

Kaatze, U. 1989. Complex permittivity of water as a function of frequency and temperature. J. Chem. and Eng. Data 34(4): 371374.

Kumcuoglu, S., S. Tavman, P. Nesvadba, and I. H. Tavman. 2007. Thermal conductivity measurements of a traditional fermented dough in the frozen state. J. Food Eng. 78(3): 1079-1082.

Liu, S., M. Fukuoka, and N. Sakai. 2013. A finite element model for simulating temperature distributions in rotating food during microwave heating. J. Food Eng. 115(1): 49-62.

Metaxas, A. C., and R. J. Meredith. 1983. Industrial Microwave Heating. Stevenage, U.K.: Peter Peregrinus, Ltd., on behalf of the Institution of Electrical Engineers.

Miyawaki, O., and R. Pongsawanit. 1994. Mathematical analysis of the effective thermal conductivity of food materials in the frozen state. Biosci. Biotech. and Biochem. 58(7): 1222-1225.

Nelson, S. O., and P. G. Bartley Jr. 2000. Measuring frequency and temperature dependent dielectric properties of food materials. Trans. ASAE 43(6): 1733-1736.

Nelson, S., and P. Bartley. 2002. Frequency and temperature dependence of the dielectric properties of food materials. Trans. ASAE 45(4): 1223-1227.

Pitchai, K., S. Birla, J. Subbiah, D. Jones, and H. Thippareddi. 2012. Coupled electromagnetic and heat transfer model for microwave heating in domestic ovens. J. Food Eng. 112(1-2): 
100-111.

Ragni, L., A. Al-Shami, G. Mikhaylenko, and J. Tang. 2007. Dielectric characterization of hen eggs during storage. J. Food Eng. 82(4): 450-459.

Rakesh, V., A. Datta, M. Amin, and L. Hall. 2009. Heating uniformity and rates in a domestic microwave combination oven. J. Food Proc. Eng. 32(3): 398-424.

Risman, P. O., and B. Wäppling-Raaholt. 2007. Retro-modelling of a dual-resonant applicator and accurate dielectric properties of liquid water from $-20^{\circ} \mathrm{C}$ to $+100^{\circ} \mathrm{C}$. Measurement Sci. and Tech. 18(4): 959-966.

Ryynänen, S. 1995. The electromagnetic properties of food materials: A review of the basic principles. J. Food Eng. 26(4): 409-429.

Ryynänen, S., P. Risman, and T. Ohlsson. 2004. Hamburger composition and microwave heating uniformity. J. Food Sci. 69(7): 187-196.

Santos, J., M. Santos, J. Dantas, M. M. Conceição, P. Athaide-Filho, and A. Souza. 2005. Comparative study of specific heat capacities of some vegetable oils obtained by DSC and microwave oven. J. Thermal Anal. and Calorimetry 79(2): 283287.

Schiffmann, R. F. 1995. Chapter 11: Microwave and dielectric drying. In Handbook of Industrial Drying, 345-372. 2nd ed. A. S. Mujumdar, ed. New York, N.Y.: Marcel Dekker.

Sears, F. W., M. W. Zemansky, and H. D. Young. 1982. University Physics. Reading, U.K.: Addison-Wesley.

Shamsudin, R., I. O. Mohamed, and N. K. M. Yaman. 2005. Thermophysical properties of Thai seedless guava juice as affected by temperature and concentration. J. Food Eng. 66(3): 395-399.

Sosa-Morales, M., L. Valerio-Junco, A. López-Malo, and H. García. 2010. Dielectric properties of foods: Reported data in the $21 \mathrm{st}$ century and their potential applications. LWT - Food Sci. and Tech. 43(8): 1169-1179.

Tang, Z., G. Mikhaylenko, F. Liu, J.-H. Mah, R. Pandit, F. Younce, and J. Tang. 2008. Microwave sterilization of sliced beef in gravy in 7 oz trays. J. Food Eng. 89(4): 375-383.
Terigar, B. G., S. Balasubramanian, and D. Boldor. 2010. An analysis of the microwave dielectric properties of solvent-oil feedstock mixtures at 300 to $3000 \mathrm{MHz}$. Bioresource Tech. 101(16): 6510-6516.

Tran, V., S. Stuchly, and A. Krasztewski. 1984. Dielectric properties of selected vegetables and fruits, 0.1-10.0 GHz. J. Microwave Power 19(4): 251-258.

Tuladhar, T., W. Paterson, and D. Wilson. 2002. Thermal conductivity of whey protein films undergoing swelling: Measurement by dynamic gauging. Food and Bioprod. Proc. 80(4): 332-339.

Wang, Y., J. Tang, B. Rasco, S. Wang, A. A. Alshami, and F. Kong. 2009a. Using whey protein gel as a model food to study dielectric heating properties of salmon fillets. $L W T-$ Food Sci. and Tech. 42(6): 1174-1178.

Wang, J., J. Tang, Y. Wang, and B. Swanson. 2009b. Dielectric properties of egg whites and whole eggs as influenced by thermal treatments. LWT - Food Sci. and Tech. 42(7): 12041212.

Wang, Y., T. D. Wig, J. Tang, and L. M. Hallberg. 2003. Dielectric properties of foods relevant to RF and microwave pasteurization and sterilization. J. Food Eng. 57(3): 257-268.

Wang, Y., J. Tang, B. Rasco, F. Kong, and S. Wang. 2008. Dielectric properties of salmon fillets as a function of temperature and composition. J. Food Eng. 87(2): 236-246.

Willix, J., S. Lovatt, and N. Amos. 1998. Additional thermal conductivity values of foods measured by a guarded hot plate. $J$. Food Eng. 37(2): 159-174.

Zhu, X., W. Guo, and X. Wu. 2012a. Frequency and temperature dependent dielectric properties of fruit juices associated with pasteurization by dielectric heating. J. Food Eng. 109(2): 258266.

Zhu, X., W. Guo, X. Wu, and S. Wang. 2012b. Dielectric properties of chestnut flour relevant to drying with radio-frequency and microwave energy. J. Food Eng. 113(1): 143-150.

Zhuang, H., S. Nelson, S. Trabelsi, and E. Savage. 2007. Dielectric properties of uncooked chicken breast muscles from ten to one thousand eight hundred megahertz. Poultry Sci. 86(11): 24332440 . 